\title{
Studi Kualitatif: Perilaku Ibu terhadap Pemberian ASI Eksklusif di Puskesmas Banemo, Kabupaten Halmahera Tengah
}

\author{
Qualitative Study: Mother's Behaviour towards Exclusive Breastfeeding in Banemo Public \\ Health Center, District of Central Halmahera
}

\author{
Santriani Samman, Andi Alim*, dan Muslimin B. \\ Fakultas Kesehatan Masyarakat, Universitas Pejuang Republik Indonesia (UPRI) Makassar, Jl. Gunung \\ Bawakaraeng No.72 Makassar, Sulawesi Selatan, Indonesia \\ *Korespondensi Penulis: andi_alimbagu@yahoo.co.id
}

Submitted: 26-10-2019, Revised: 02-07-2020, Accepted: 15-08-2020

DOI: https://doi.org/10.22435/mpk.v30i2.2397

\begin{abstract}
Abstrak
Salah satu upaya untuk memperoleh tumbuh kembang bayi yang baik adalah dengan pemberian Air Susu Ibu (ASI) eksklusif sampai enam bulan. ASI merupakan makananan alami yang pertama untuk bayi yang memberikan semua vitamin, mineral, dan gizi yang dibutuhkan oleh bayi untuk pertumbuhan selama enam bulan pertama dan tidak ada makanan atau cairan lain yang diperlukan. Penelitian ini bertujuan untuk mengetahui perilaku ibu terhadap pemberian ASI eksklusif kepada anak di wilayah kerja Puskesmas Banemo Kabupaten Halmahera Tengah. Penelitian ini merupakan penelitian kualitatif dengan pendekatan fenomonologi untuk mengetahui informasi yang mendalam tentang perilaku ibu terhadap pemberian ASI eksklusif dengan jumlah informan pada penelitian ini adalah 7 informan yang terdiri dari 1 informan kunci, 3 informan pendukung, dan 3 informan biasa. Penelitian menunjukkan bahwa kurangnya pengetahuan ibu tentang manfaat akan pentingnya ASI eksklusif membuat ibu tidak memberikan ASI eksklusif kepada bayinya. Pekerjaan ibu sebagai ibu rumah tangga membuat ibu dapat mengatur antara pekerjaan rumah dengan menyusui. Tidak ada perawatan khusus pada payudara ibu dalam mempersiapkan kelahiran anak karena payudara informan normal. Kurangnya pengetahuan ibu tentang ASI eksklusif sehingga disarankan kepada petugas kesehatan agar meningkatkan pengetahuan ibu menyusui melalui penyuluhan dan disarankan pula kepada ibu menyusui agar melakukan persiapan kelahiran anak dengan melaksanakan perawatan payudara agar tidak lecet pada saat menyusui.
\end{abstract}

Kata Kunci: ASI eksklusif; perilaku; pengetahuan; pekerjaan; tindakan

\begin{abstract}
One effort to obtain a good baby growth and development is by giving exclusive breastfeeding up to 6 months. Breastmilk is the first natural food for babies that provide all the vitamins, minerals and nutrients needed by babies for growth during the first six months and no food or other fluids are needed. This study aimed to determine the behaviour of mothers towards exclusive breastfeeding for children in the working area of Banemo Public Health Center in Central Halmahera District. This research was qualitative with a phenomenological approach to find out in-depth information about mother's behaviour towards exclusive breastfeeding. The number of informants in this study were 7 informants consisting of 1 key informant, 3 supporting informants, and 3 regular informants. Research showed that mothers' lack
\end{abstract}


of knowledge about the benefits of the importance of exclusive breastfeeding makes mothers not give exclusive breastfeeding to their babies. The work of nursing mothers as housewives allows mothers to manage berween household chores and breastfeeding. There was no special treatment for the mother's breast in preparation for child birth because the breast of the informant was normal. There was mothers' lack of knowledge about exclusive breastfeeding, so it is recommended for health workers to increase knowledge of breastfeeding mothers through counselling and it is also advisable for breastfeeding mothers to prepare for child birth by carrying out breast care so that the do bot get blistered during breastfeeding.

Keywords: exclusive breastfeeding, behaviour; knowledge; work; action

\section{PENDAHULUAN}

Air Susu Ibu (ASI) eksklusif adalah cairan putih yang dihasilkan oleh kelenjar payudara ibu melalui proses menyusui dan ASI juga memiliki komposisi gizi yang paling lengkap untuk pertumbuhan dan perkembangan bayi. ${ }^{1}$ Melihat manfaat yang sangat besar, maka pemberian ASI eksklusif sangat dianjurkan. Yang dimaksud dengan ASI eksklusif adalah pemberian ASI selama enam bulan tanpa makanan tambahan lain seperti susu formula, jeruk, madu, air teh, air putih, dan makanan padat seperti pisang, pepaya, bubur, biskuit, bubur nasi, dan tim sejak lahir hingga bayi umur 6 bulan. ${ }^{2}$ Ibu menyusui harus cermat dalam menyusun pola makan. Selain pola makan yang seimbang, ibu menyusui juga harus cermat dalam memilih bahan makanan yang dapat memperlancar produksi ASI. Ibu menyusui sebaiknya memperbanyak konsumsi sayuran dan buah-buahan. ${ }^{3}$ Status gizi ibu menyusui memegang peranan penting untuk keberhasilan menyusui yang indikatornya diukur dari durasi ASI eksklusif, pertumbuhan bayi dan status gizi ibu pasca-menyusui. ${ }^{4}$

Menyusui dalam jangka panjang dapat memperpanjang jarak kelahiran karena masa amenorhoe lebih panjang. United Nations Children's Fund (Unicef) dan World Health Organization (WHO) membuat rekomendasi pada ibu untuk menyusui eksklusif selama enam bulan kepada bayinya. Sesudah umur enam bulan, bayi baru dapat diberikan Makanan Pendamping ASI (MP-ASI) dan ibu tetap memberikan ASI sampai anak berumur dua tahun. Pemerintah
Indonesia melalui Kementerian Kesehatan juga merekomendasikan para ibu untuk menyusui eksklusif selama enam bulan kepada bayinya. ${ }^{5}$

Perilaku ibu dalam memberikan ASI eksklusif ini dipengaruhi oleh berbagai faktor, salah satunya adalah pengetahuan ibu terkait dengan pemberian ASI eksklusif. Berdasarkan informasi awal dari masyarakat Banemo bahwa tidak pernahnya dilakukan penyuluhan atau pemberitahuan informasi tentang ASI eksklusif yang dilakukan oleh petugas Kesehatan Ibu dan Anak (KIA), bidan atau petugas Pusat Kesehatan Masyarakat (puskesmas) lainnya.

Selain itu kebanyakan ibu menyusui di wilayah kerja Puskesmas Banemo memiliki tingkat pendidikan yang masih rendah. Sehingga akan berdampak pada kurangnya pengetahuan dan pemahaman ibu tentang pemberian ASI eksklusif.

Sebagian ibu-ibu menyusui tersebut lebih memilih bekerja daripada mereka memberikan ASI eksklusif kepada anaknya. Pemberhentian pemberian ASI eksklusif kepada bayi mereka disebabkan oleh ketergantungan terhadap pemberian susu formula. Selain itu mereka tidak memberikan ASI eksklusif kepada anak dikarenakan perkawinan dini bagi ibu-ibu muda atau yang hamil di luar nikah. Dengan demikian tentunya pengetahuan akan pemberian ASI eksklusif sangat minim dikarenakan kesiapan menjadi seorang ibu yang belum ada.

Walaupun usia bayi belum cukup sampai enam bulan, para ibu tersebut sudah tidak mau lagi menyusui bayinya. Salah satu faktornya 
karena mereka berfikir bahwa sudah ada bantuan susu formula yang bisa membuat bayi mereka cepat tumbuh dan berkembang dengan baik, dengan mengonsumsi susu formula. Bahkan mereka beranggapan bahwa susu formula lebih mencerdaskan anaknya daripada pemberian ASI eksklusif. Salah satu yang perlu dicermati bahwa mereka lebih percaya dengan promosi susu formula di iklan televisi (TV) dan majalah yang mereka nonton.

Pemberian ASI eksklusif sebagian terkendala karena pengetahuan, tetapi juga ibu menolak untuk menyusui anaknya karena akan berpengaruh pada bentuk fisik badan si ibu yang semakin gemuk jika bayi menyusui. Selain itu, ibu bayi cepat merasa lapar dan selalu ingin makan, sehingga badannya semakin gemuk (mengurangi kecantikan). Maka dari itu, si ibu bayi berupaya menstabilkan badannya, walaupun anaknya masih berumur 0-4 bulan dengan hanya hanya menggunakan susu formula. Kurangnya pengetahuan ibu tentang pentingnya ASI eksklusif dimungkinkan dari promosi produkproduk makanan tambahan dan susu formula yang dianjurkan oleh petugas kesehatan sendiri apabila bayi sulit menyusu. Kemajuan teknologi dan komunikasi, serta gencarnya promosi susu formula sebagai pengganti ASI, membuat masyarakat kurang mempercayai kehebatan ASI, sehingga akhirnya memilih susu formula sebagai pengganti ASI eksklusif. ${ }^{6}$

Bagi ibu yang aktif bekerja di luar rumah banyak waktu tersita untuk mencari sumber tambahan dalam upaya pemenuhan kebutuhan hidupnya, sehingga dalam pemberian ASI eksklusif sering kali mengalami hambatan karena singkatnya masa cuti hamil dan melahirkan. Akibatnya, terkadang mereka memilih untuk menggunakan susu formula karena dianggap sangat menguntungkan. Disamping itu dengan maraknya iklan yang berkaitan tentang susu formula, menyebabkan ibu yang memiliki pengetahuan yang rendah akan ASI eksklusif beranggapan bahwa penggunaaan susu formula jauh lebih baik dibandingkan dengan ASI. Susu formula dianggap memiliki nilai ekonomis dan kandungan gizinya banyak berdasarkan pada komposisi yang tertera pada kemasan susu formula tersebut. Keadaan seperti itu yang sering menjadi kendala bagi ibu untuk memberikan ASI eksklusif sehingga pemberian ASI eksklusif mungkin tidak tercapai. ${ }^{7}$

Unicef memperkirakan bahwa pemberian ASI eksklusif sampai usia enam bulan dapat mencegah kematian 1,3 juta anak berusia di bawah lima tahun. ${ }^{8}$ WHO menghimbau untuk memberikan ASI eksklusif tanpa makanan lain kepada bayi sejak lahir 0-6 bulan kecuali obat dan vitamin. Pemberian ASI eksklusif bukan berarti bahwa pemberian ASI hanya dilakukan selama 6 bulan saja, namun pemberian ASI tetap diberikan kepada anak atau bayi sampai berusia dua tahun. ${ }^{9}$

ASI dibedakan menjadi 3 (tiga) tahap yaitu kolostrum, ASI transisi, ASI matur. Kolostrum adalah ASI yang dikeluarkan ibu beberapa hari setelah melahirkan, berwarna kuning, dan mengandung antibodi. ASI transisi biasanya dihasilkan dalam 2 minggu pasca melahirkan, dan kemudian selanjutnya menjadi ASI matur yang akan diberikan sampai waktu menyapih. Banyak kebiasaan salah yang dilakukan ibu di Indonesia dalam menyusui bayinya. Mereka enggan memberikan cairan ASI yang berwarna putih dan cairan yang kental berwarna kuning atau kolostrum karena dianggap dapat menyebabkan sakit perut. Oleh karena itu sebelum susu matur (ASI) keluar, bayi diberikan makanan pengganti seperti air gula dan madu. Akibat dari kurangnya pemahaman tersebut maka merugikan kesehatan bayi itu sendiri. ${ }^{10}$

Berdasarkan data dari profil Puskesmas Banemo Kabupaten Halmahera Tengah tahun 2018, tingkat pencapaian pemberian ASI eksklusif berdasarkan survei program gizi tahun 2018 adalah 64,46\%. Pencapaian tersebut masih sangat rendah bila dibandingkan dengan target yang diharapkan yaitu $80 \%$ bayi yang mendapatkan ASI eksklusif. Jumlah bayi yang mendapatkan ASI di tahun 2018 dari 408 bayi hanya 263 yang diberikan ASI eksklusif. ${ }^{11}$ 
Berdasarkan fenomena dan permasalahan di atas, maka penulis tertarik untuk mengkaji dan menggali lebih mendalam tentang bagaimana perilaku ibu terhadap pemberian ASI eksklusif di wilayah kerja Puskesmas Banemo Kabupaten Halmahera Tengah.

\section{METODE}

Jenis penelitian menggunakan pendekatan kualitatif untuk menggali informasi yang mendalam tentang bagaimana perilaku ibu terhadap pemberian ASI eksklusif di wilayah kerja Puskesmas Banemo Kabupaten Halmahera Tengah. Penggunaan metode pada penelitian ini diharapkan dapat memahami perilaku ibu dalam pemberian ASI eksklusif kepada anak. Sedangkan pendekatan fenomonologi bertujuan untuk menggambarkan makna dari pengalaman hidup yang dialami oleh beberapa individu, tentang konsep atau fenomena tertentu, dengan mengeksplorasi struktur kesadaran manusia.

Tempat penelitian ini dilaksanakan di wilayah kerja Puskesmas Banemo Kabupaten Halmahera Tengah dan waktu penelitian dimulai pada bulan Juni sampai dengan bulan Agustus 2019. Informan dalam penelitian ini adalah petugas Kesehatan Ibu dan Anak (KIA) 1 orang, bidan 2 orang, kader 1 orang, dan ibu menyusui 3 orang. Teknik pengumpulan data yang digunakan adalah interview (wawancara), observasi, dan dokumentasi. Penentuan informan berdasarkan dari informasi masyarakat setempat dengan snowball sampling. Analisis data pada penelitian ini menggunakan konsep yang diberikan Miles dan Huberman yang mengemukakan bahwa motivasi dalam analisis data kualitatif dilakukan secara interaktif dan berlangsung secara terusmenerus pada setiap tahapan penelitian sehingga sampai tuntas dan datanya sampai jenuh. Sedangkan, pengolahan data dianalisis dengan menggunakan analisis isi (content analysis) yaitu dengan mengumpulkan semua data atau informasi yang sama dan dapat mewakili informasi yang diinginkan. Kemudian data disajikan dalam bentuk metamatriks dan diinterpretasikan dalam bentuk naskah (narasi). Penelitian ini telah melewati proses pemeriksaan protokol penelitian dan memperoleh Surat Keterangan Lolos Kaji Etik oleh Komite Etik Penelitian Kesehatan Fakultas Kesehatan Masyarakat Universitas Pejuang Republik Indonesia.

\section{HASIL}

Penelitian ini dilakukan terhadap informan dengan interval umur antara 25 sampai 42 tahun. Untuk jenis kelamin informan, semua berjenis kelamin perempuan. Sedangkan, untuk tingkat pendidikan informan antara lain Strata-1 (S1) Kesehatan Masyarakat 2 orang, Diploma (D3) 1 orang, SMA 1 orang, dan SD 3 orang.

Tabel 1. Distribusi Informan berdasarkan Jenis Kelamin, Umur dan Pendidikan

\begin{tabular}{ccccl}
\hline Kode & JK & Umur & Pendidikan & $\begin{array}{c}\text { Status } \\
\text { Informan }\end{array}$ \\
\hline HM & P & 42 & D3 & Kunci \\
JR & P & 37 & S1 & Pendukung \\
HB & P & 35 & S1 & Pendukung \\
NW & P & 37 & SMA & Pendukung \\
WT & P & 25 & SD & Biasa \\
RM & P & 33 & SD & Biasa \\
RK & P & 33 & SD & Biasa \\
\hline
\end{tabular}

\section{Pengetahuan}

\section{Pengetahuan Ibu tentang ASI Eksklusif}

Dari hasil wawancara dengan informan tentang bagaimana pengetahuan ASI eksklusif, berikut ini hasil wawancaranya:

\section{"Kalau masalah ASI eksklusif sudah banyak ibu-ibu yang tahu di sini karena kami sering penyuluhan sama ibu sejak masih hamil." (HM, 42 thn., 10/07/2019)}

Berdasarkan hasil kutipan, HM menyatakan bahwa kebanyakan ibu mengetahui tentang ASI eksklusif karena petugas kesehatan sering melakukan penyuluhan kepada ibu-ibu sejak hamil. Berbeda dengan apa yang diungkapkan oleh informan JR yang menyatakan hampir semua ibu sudah diberitahukan tentang ASI eksklusif, akan tetapi tidak diterapkan dikarenakan ibu 
malas memberi ASI eksklusif kepada anaknya, sebagaimana hasil wawancara informan di bawah ini,

"Sebenarnya kalau masalah ASI eksklusif sudah semua ditanya, mereka tau tapi begitu tidak diterapkan, baru kalau disuruh kasih menyusui anaknya, mereka banyak alasannya." (JR, 37 thn., 10/07/2019)

Sedangkan HB berpendapat bahwa ibu mengetahui tentang ASI eksklusif, hanya saja ibu tidak melakukan sesuai apa yang diketahui karena ibu hanya malas menyusui. Sebagaimana hasil wawancaranya:

"Kalau saya liat ada yang tau ada juga yang tidak tau karena biasa ditanya ibu-ibu dia bilang dia tau tapi tidak melakukan, jadi saya pikir mungkin tidak tau atau malas kasih menyusui anaknya padahal sering ditanya." (HB, 25 thn., 10/07/2019)

Berdasarkan hasil wawancara dengan informan NW, ibu dianggap telah mengetahui apa itu ASI eksklusif dan juga mempraktikkan pemberian ASI saja hingga bayi berumur 6 bulan. Sebagaimana hasil wawancara:

"Kalau saya lihat dia (ibu) tau tentang ASI eksklusif karena dia menyusui anaknya hingga 6 bulan tanpa memberikan apapun kecuali ASI." (NW, 25 thn., 10/07/2019).

Informan biasa mengatakan hal yang berbeda mengenai ASI eksklusif, ada yang mengetahui ada juga yang tidak, berikut hasil wawancaranya:

"Biasa saya dengannya tapi saya lupa-lupa, apakah lagi itu artinya, poko'nya dia kasih susu anaknya sampai umur 2 tahun." (WT, 25 thn., 10/07/2019)

Informan WT tidak memiliki pengetahuan tentang ASI eksklusif, dia hanya mengetahui bahwa ibu menyusui hingga anak berusia dua tahun. Sedangkan informan RM pernah ditanya ASI eksklusif tapi RM sering lupa. RM mengatakan kalau menyusui anak atau bayinya dengan ASI bagus untuk anak/bayinya. Sebagaimana hasil wawancara dengan informan RM di bawah ini:

"Pernah saya ditanya tapi lupa, kalau tidak salah pokoknya tentang disusui anaknya, poko'nya bagus itu ASI untuk anak-anak." (RM, 33 thn., 10/07/2019)

Informan RK mengetahui bahwa ASI eksklusif berarti ibu memberikan ASI saja sampai bayi berumur enam bulan tanpa diberikan makanan tambahan, meskipun RK masih raguragu dalam memberikan jawaban sebagaimana kutipan wawancara dengan informan $\mathrm{RK}$ di bawah ini.

"Eeeeee...kayanya itu ASI eksklusif, itu yang menyusui anak sampai umur 6 bulan. Pokonya ASI saja saya kasih tidak ada campuran dengan makanan lain." (RK,33 thn., 10/07/2019)

\section{Pengetahuan tentang Kolostrum}

Dari hasil wawancara dengan informan di bawah ini tentang bagaimana pengetahuan tentang kolostrum, berikut ini hasil wawancaranya:

"Pada dasarnya ibu-ibu di sini suda tahu
apa itu kolostrum, bagaimana ciri-cirinya,
apa manfaatnya, jadi jika menyusui tidak
pernah lagi dia buang." (HM,42 thn.,
10/07/2019)

Berdasarkan hasil dari informan HM, bahwa ibu-ibu sudah tahu apa manfaat dari kolostrum. Jadi, mereka tidak lagi membuangnya, namun tetap memberikan pada saat menyusui anak bayinya. Demikian juga apa yang disampaikan oleh informan JR yaitu semua ibu-ibu di sana sudah tahu tentang kolostrum, sebelumnya mereka tidak tahu hal tersebut. Dan mereka sudah mengetahuinya karena ibu-ibu sudah dengar dari petugas kesehatan. 
"Kalau masalah kolostrum rata-rata ibuibu di sini sudah tahu, tidak seperti dulu memang banyak yang tidak tahu. Sekarang semua pada tahu." (JR, 35 thn., 10/07/2019)

Kurangnya pengetahuan dan pendidikan yang didapatkan oleh ibu-ibu disana menyebabkan sering terjadinya penyakit pada anak bayi yang tidak diinginkan oleh masyarakat. Dikarenakan tidak adanya informasi yang disampaikan pada masa lalu yang terkait dengan pemberian ASI eksklusif, sehingga masyarakat kurang mengetahui hal tersebut. Tetapi, sekarang dengan adanya informasi-informasi yang didapatkan, sehingga ibu-ibu sudah dapat mengetahui apa itu kolostrum.

Informan HB juga berpendapat yang sama dengan informan HM, yang menyatakan jika ibuibu di daerah tersebut telah memiliki pengetahuan mengenai kolostrum, sehingga di hari pertama saat saat bayi lahir ibu tidak membuangnya dan menyusukan ke anaknya.

"Kalau masalah kolostrum di tau ibuibu disini, kalau menyusui tidak pernah di buang karena dia tau manfaatnya" (HB, 35 thn., 10/07/2019)

Adapun informasi dari NW menyatakan bahwa informan mengetahui jika kolostrum yang keluar pada hari pertama dan diberikan kepada bayi, maka bayi tersebut akan sehat serta terhindar dari penyakit, karena fungsi kolostrum merupakan antibodi atau sebagai kekebalan tubuh pada bayi.

"kalau saya liat ibu-ibu di sini mereka tau kalau kolostrum karena suda ditanya kalo kolostum keluar pada saat pertama kali menyusui, warnanya agak kuning dan bagus untuk bayi ibu, bisa kasi kuat anak dan tidak sakit-sakit." (NW, 37 thn., 10/07/2019).

Sedangkan kutipan informan WT mengungkapkan bahwa ibu tahu tentang kolostrum, yaitu ASI yang pertama kali keluar dan manfaatnya dapat meningkatkan kekebalan anak. Pengetahuan dari informan WT tentang kolostrum cukup baik, sebagaimana dapat dilihat dari hasil wawancara yang menunjukkan bahwa ibu tersebut mengetahuinya.

\begin{abstract}
"Kalau itu saya tau bu, itu to yang warnanya kuning, kalo menyusui paling pertama keluar, itu katanya memang bagus untuk bayi, karena bayi kuat." (WT, 25 Thn., 10/07/2019).
\end{abstract}

Begitupun dengan informan RM, ketika ditanya tentang kolostrum, ibu mengetahui akan manfaat, kegunaan, dan warna atau teksturnya. Ibu tersebut tidak membuangnya dan selanjutnya memberikan kepada bayinya.

"Iya saya tau itu, itu yang warnanya kuning to bu, bagus memang katanya itu untuk bayi jadi tidak boleh dibuang, karena itu adalah vitaminnya, saya waktu menyusui anakku, tidak ku buang karena itu membuat anak $k u$ kuat" (RM, 25 Thn., 10/07/2019)

Pengetahuan yang dimiliki oleh informan RK berbeda, karena mengutarakan pernah mendengarnya tapi tidak mengetahui apa namanya. Tapi ibu RK mengetahui warna kolostrum pada saat ASI keluar.

"Pernah saya dengar itu bu, saya tidak tau namanya tapi saya tau itu warnanya kaya kuning-kuning, pertama sekali keluar kalau mau menyusui" (RK, 25 thn., 10/07/2019)

Hasil wawancara dengan informan di atas, tentang pengetahuan kolostrum hanya satu informan yang jawabannya berbeda, sedangkan yang lainnya mengetahui tentang kolostrum.

\section{Pengetahuan Ibu tentang Manfaat dan Keuntungan ASI}

Hasil wawancara dengan informan tentang bagaimana pengetahuan tentang manfaat dan keuntungan ASI eksklusif dapat dilihat berikut ini: 


\begin{abstract}
"Yang saya liat-liat ibu di sini, mereka tau manfaatnya itu ASI eksklusif tapi tidak dikasi ASI eksklusif mereka cepat sekali kasi makanan tambahan kepada anaknya." (HM, 42 thn., 10/07/2019).
\end{abstract}

Berdasarkan hasil kutipan wawancara, HM mengatakan bahwa ibu mengetahui manfaat ASI eksklusif tapi ibu tidak memberikan ASI eksklusif kepada bayinya. Ibu lebih memilih memberikan makanan tambahan kepada anak atau bayinya agar dapat tumbuh lebih cepat. Dengan pengetahuan ibu yang kurang maka mereka berfikir jika cepat diberikan makanan pendamping, maka si bayi akan lebih cepat tumbuh dan besar.

Hal tersebut berbeda dengan apa yang disampaikan oleh informan JR, yaitu ibu mengetahui manfaat ASI eksklusif tapi ibu tidak memberikan ASI eksklusif, dan memberikan makanan tambahan ketika bayi baru berusia 4 bulan (kurang dari 6 enam bulan). Ibu tersebut beranggapan bahwa anak atau bayinya lambat tumbuh dikarenakan ASI-nya tidak cukup untuk diberikan kepada bayinya sehingga diberikan makanan pendamping agar anak dapat tumbuh lebih cepat.

"Sebenarnya ibu-ibu tau itu ASI eksklusif, Cuma mereka tidak kasi ASI eksklusif karena ibu-ibu kalo sudah lihat anaknya sudah besar mereka kira tidak cukup ASI-nya, biasa baru 4 bulan, sudah di kasi makanan." (JR, 37 thn., 10/07/2019)

Dengan memiliki pendidikan dan pengetahuan khususnya tentang kesehatan pada bayi, maka masyarakat akan lebih tahu dampak negatif dari perilaku yang tidak sehat baik kepada dirinya maupun kepada bayi mereka.

HB berpendapat bahwa sebenarnya ibu mengetahui manfaatnya ASI tapi tidak menerapkannya. Penyebabnya karena ASI ibu tidak lancar sehingga bayi baru yang berusia 4 bulan sudah diberikan makanan pendamping seperti bubur saring. Hal ini dikarenakan ibu tidak peduli untuk berbuat sesuatu agar ASInya lancar atau ibu tidak mengkonsumsi makanan yang bergizi untuk kebutuhan bayinya sehingga ASI bisa tetap lancar.

"Kalau ditanya ibu-ibu, dia tau semua tapi baru 4 bulan anaknya dikasi makanan, dia bilang tidak bisa kalau tidak dibantu sama makanan karena tidak cukup ASInya jadi harus dibantu sama makanan seperti bubur saring." (HB, 25 thn., 10/07/2019)

Informan NW juga berpendapat seperti informan yang lain, bahwa pengetahuan mengenai ASI eksklusif ibu tidak diterapkan. Bayi si ibu yang belum cukup sampai umur enam bulan sudah diberikan makanan pendamping.

"Heran juga lihat ibu-ibu semua, dia tau manfaatnya itu ASI Eksklusif tapi tidak di kasi anaknya, katanya biar cepat besar anaknya karena kalau di kasi ASI saja tidak cukup, jadi belum cukup enam bulan suda dikasi bubur kepada anaknya." (NW, 37 thn., 10/07/2019)

Informan biasa mengatakan hal yang berbeda-beda mengenai manfaat dan keuntungan ASI eksklusif, ada yang mengetahui manfaatnya ada juga yang tidak mengetahuinya. Berikut ini hasil wawancaranya:

"Saya tidak tau itu, saya susui anakku saja yang penting mau menyusui, kalau bisa makanan saya kasi makanan karna kalo sudah usia 4 bulan sampai 5 bulan itu sudah bisa makan." (WT, 25 thn., 10/07/2019).

Informan WT tidak mengetahui manfaat dan keuntungan ASI eksklusif. Baginya yang penting ibu tetap bisa menyusui, dan bayi bisa diberikan makanan. WT bahkan beranggapan bahwa bayi yang sudah berusia empat bulan atau lima bulan itu sudah bisa diberi makan.

Informan RM mengatakan sudah biasa mendengar perihal ASI eksklusif namun tidak begitu mengetahui manfaat ASI eksklusif. Ibu memberikan ASI dan menyusui anaknya agar 
tidak menangis, sebab tangisan bayi dianggap sebagai petanda bayi lapar. Ibu akan memberi makan bayijika dalam perkiraannya bayi dianggap sudah besar. Ibu tidak dapat menentukan pada usia berapa bayi diberikan makanan tambahan, mereka hanya menduga berdasarkan ukuran fisik bayi saja.

"Tidak begitu tau, biasa saya dengar tapi tidak tau apa manfaatnya, yang penting saya susui anakku supaya tidak menangis karena kentara kalau lapar pasti menangis, jadi saya kalau lihat anakku sudah besar, saya bikin bubur." (RM, 33 thn., 010/07/2019).

Hasil wawancara informan RK menunjukkan bahwa ibu memiliki pengetahuan tentang ASI eksklusif. Akan tetapi ASI ibu tidak mencukupi untuk diberikan kepada bayinya sehingga mereka beranggapan kalau bayi cepat diberi makan maka pertumbuhan dan perkembangnya lebih cepat, walaupun ibu tahu bahwa ASI dapat mencegah penyakit-penyakit pada bayi.

"Saya tau itu bu, tapi biasa juga tidak cukup ASI baru itu anak masih mau menyusui, jadi di kasi makanan bubur, cepat juga anak besar kalau di kasi makanan, bagus katanya itu ASI, anak jadi tidak sakit-sakit tapi mau bagaimana kalau tidak cukup ASIku" (RK, 33 thn., 03/07/2019).

\section{Pengetahuan Ibu tentang Akibat Jika Bayi Tidak Diberikan ASI Eksklusif}

Di bawah ini disampaikan hasil wawancara dengan informan di bawah ini tentang bagaimana pengetahuan tentang akibat jika bayi tidak diberikan ASI eksklusif.

"Terkadang ibunya tau tapi tetap tidak dikasi ASI eksklusif kepada anak nya, padahal dia tau apa akibat nya kalo bayi tidak di berikan ASI eksklusif." (HM, 42 thn., 03/07/2019)
Berdasarkan hasil kutipan dari HM, bahwa ibu tidak memberikan ASI eksklusif kepada bayinya walaupun ibu sudah mengetahui akan risiko jika bayi tidak diberikan ASI eksklusif dan mereka beranggapan tidak akan terjadi hal yang buruk kepada bayinya. Sedangkan menurut informasi dari JR, terlepas apakah ibu benarbenar mengetahui akibat memberikan makanan tambahan lebih cepat dari umur yang dianjurkan kepada bayinya, secara umum biasanya mereka menyebutkan bahwa bayi akan mengalami gangguan pencernaan maupun angka kesakitan seperti terkena diare.

"Kurang tau itu, dia tau atau tidak, tapi biasa di tanya itu ibu-ibu mengenai akibatnya kalo ibu terlalu cepat dikasi makan bayinya karena bayi belum kuat pencernaanya, bayi bisa diare." (JR, 37 thn., 03/07/2019)

Dengan pendidikan dan pengetahuan yang dimiliki masyarakat khususnya tentang kesehatan, maka masyarakat akan tahu efek negatif dari perilaku yang tidak sehat yang menyebabkan bayi bisa terkena penyakit diare.

Menurut HB, sudah sering disampaikan bahwa hanya ASI eksklusif yang boleh diberikan pada bayi, tetapi para ibu tetap memberikan makanan pendamping. Dengan alasan bahwa memberikan makanan pendamping membuat bayi lebih cepat gemuk, walaupun mereka sudah mengetahui kalau memberi makanan kepada bayi sebelum usia enam bulan akan mengakibatkan bayi kurang kekebalan tubuhnya.

"Itu juga susahnya biasa itu ibu-ibu selalu di tanya, kasi Eksklusif anak tapi cepat di kasi makan katanya biar anaknya cepat besar, kalo cepat dikasi makan anak bisa gemuk, padahal kalo cepat kasi makan, kurang kekebalan tubuhya itu bayinya." (HB, 35 thn., 03/07/2019) 
Informan NW berpendapat kalau para ibu sudah mengetahui mengenai dampak hal tersebut, namun demikian mereka terpengaruh melihat anak tetangga yang berusia empat bulan sudah diberi makan, dengan alasan anak dapat tumbuh kembang dengan cepat.

"Kayanya ibu tau, Cuma biasa terpengaruh
sama anak tetangganya, kalau lihat anaknya
orang gemuk, jadi mau begitu tanpa dia
pikirkan akibatya kalo itu anak cepat di
beri makan, anak bisa kurang kekebalanya
karena kurang mendapatkan ASI." (NW, 37
thn., 03/07/2019)

Pemberian ASI eksklusif sangat dianjurkan pada bayi umur 0-6 bulan karena ASI mengandung gizi yang lengkap untuk pertumbuhan dan perkembangan bayi. Tetapi ibu bayi tidak menerapkan karena mereka lebih terpengaruh melihat perkembangan dari anak bayi tetangga, tanpa memperhitungkan akan penyakit di kemudian hari yang dapat timbul terhadap bayi mereka. Hal tersebut tidak sesuai dengan apa yang ditargetkan oleh WHO atau pemerintah. Pada awalnya WHO menganjurkan pemberian ASI eksklusif dilakukan dari bayi berusia 0-4 bulan. Namun anjuran itu dirubah agar ASI Eksklusif diberikan sampai anak usia 6 bulan. ${ }^{13}$

Informan biasa mengatakan hal yang berbeda mengenai jika bayi tidak diberi ASI eksklusif, berikut ini hasil wawancaranya:

"Dibilang orang bagus kalu anak dikasi susu lama tapi biasa juga bu kalo disusui saja anak gemuk baru sehat dilihat, jadi pikir tidak ada akibat kalo anak cepat dikasi makan." (WT, 25 thn., 10/07/2019).

Informan WT berpikir bayi akan lambat pertumbuhannya apabila bayi diberi ASI dalam waktu yang lama. Maka dari itu, ibu memberi makan kepada bayinya agar bayi bisa bertambah gemuk dan tumbuh lebih cepat. Dan tentunya ibu tidak mengetahui bahwa bayi yang diberi makan sebelum enam bulan dapat berakibat terserang diare, sembelit, batuk-pilek dan panas, jika dibandingkan dengan bayi yang diberi ASI esklusif saja.

Menurut informasi dari RM, ibu mengetahui tentang pemberian ASI eksklusif. Namun ibu tetap memberi makan kepada bayinya dengan alasan bahwa memberikan makanan pendamping membuat bayi jauh lebih sehat dan berkembang. Menurut mereka jika hanya diberi ASI saja, maka bayi cepat lemas.

"Katanya memang tidak baik kalo itu anak cepat dikasi makan tapi tidak dilihat bahkan tambah sehat saya lihat anak saya makan, kalo di susu saja itu anak loyo karena tidak puas kalau makan saja." (RM, 33 thn., 03/07/2019).

\section{Pekerjaan Ibu \\ Jenis Pekerjaan dan Lama Bekerja}

Dari hasil wawancara dengan informan di bawah ini tentang bagaimana jenis pekerjaan dan lama bekerja, berikut hasil wawancaranya:

"Kalo pekerjaan tidak ada, cuma ibu rumah tangga, tidak ada pekerjaan. Itu saja pekerjaan rumah seperti mencuci sama memasak, kalo lamanya biasa selesai pekerjaan jam 11, itupun sudah masak." (HM, 42 thn., 10/07/2019)

Berdasarkan hasil kutipan informan HM bahwa ibu hanya bekerja sebagai ibu rumah tangga. Pekerjaan yang dilakukan hanya memasak dan mencuci, dan pekerjaan tersebut sudah selesai menjelang siang hari sehingga waktu untuk mengurus bayinya lebih banyak setelah pekerjaan rumah terselesaikan. Begitupun dengan informan JR, yang hanya mengurusi pekerjaan rumah tangga seperti informan HM.

"Tidak ada pekerjaan, Cuma itu pekerjaan di rumah seperti memasak, mencuci, membersihkan rumah, tidak lama bekerja, paling sekitar jam 11 selesai." (JR, 37 thn., 03/07/2019). 
Sedangkan informan HB, walaupun mempunyai pekerjaan berjualan dengan membuka usaha kecil-kecilan di rumah dalam pemenuhan kebutuhan hidupnya, masih dapat mengatur waktunya untuk menyelesaikan pekerjaan rumah tangga dan mengurus anak atau bayinya jika pembeli tidak ada. Berikut ini hasil wawancaranya:

"Kalau saya pekerjaan saya menjual-jual tapi di rumah kalau tidak ada orang belanja memasak jadi menjual sambil selesaikan pekerjaan rumah tangga." (HB, 35 thn., 10/07/2019).

\section{Selama Bekerja Bayi tetap Diberikan ASI}

Dari hasil wawancara dengan informan di bawah ini tentang bagaimana bekerja apakah bayi tetap diberi ASI, berikut hasil wawancaranya:

"Iya pasti itu dikasih susu, karena bisa bekerja sambil dikasi susu juga itu anak" (HM, 42 thn., 10/07/2019).

Berdasarkan hasil kutipan dari informan HM, bahwa ibu memberikan ASI kepada bayinya karena ibu bisa mengatur waktunya, jika anak bayinya diberikan ASI dan sudah kenyang tentunya si bayi akan tidur kembali, sehingga ibu bisa melanjutkan pekerjaannya. Begitupun dengan kutipan dari informan JR, ibu juga melakukan hal yang sama seperti yang dilakukan informan HM.

"Iya jadi biasanya saya kasi susu dulu, kalo sudah tidur baru saya memasak sama mencuci." (JR, 37 thn., 10/07/2019).

Dari kutipan informan HB, walaupun memiliki aktivitas yang lain yaitu membuka usaha kecil-kecilan di rumah untuk memenuhi kebutuhan hidupnya, pada prinsipnya si ibu dapat mengatur waktunya. Kalau tidak ada yang belanja, untuk melakukan pekerjaan rumah seperti memasak, mencuci, dan mengurus anak atau bayinya.

\begin{abstract}
"Kalo saya menjual saya kasi menyusui juga, kalo tidur saya membersihkan rumah sama memasak atau mencuci, jadi tetap dikasi susu bagaimana kalo tidak kasi susu pasti menangis." (HB, 35 thn., 03/07/2019).
\end{abstract}

\section{Pekerjaan Mempengaruhi Pemberian ASI}

Dari hasil wawancara dengan informan di bawah ini tentang bagaimana pekerjaan ibu, apakah mempengaruhi ASI berikut hasil wawancaranya:

"Kalo saya tidak diganggu karena bisa saya selang-seling, kalo saya sudah selesai masak, saya kasih susu, kalo sudah tidur saya kerja lagi yang lain" (HM, 42 thn., 10/07/2019).

Berdasarkan hasil wawancara dengan informan HM, bahwa ibu sama sekali tidak terganggu antara melakukan pekerjaan rumah dengan pemberian ASI kepada bayinya karena ibu bisa mengatur waktu. Jika anaknya menangis maka ibu memberikan ASI kepada bayinya sampai bayi tersebut tertidur sehingga ibu dapat melanjutkan pekerjaan. Jadi ibu merasa tidak terganggu karena ibu merasa bahwa itu sudah menjadi tanggung jawab sebagai ibu. Sedangkan informan JR mengatakan pemberian ASI tidak mengganggu pekerjaan, tetapi terkadang ibu sering mengeluh karena faktor pekerjaan yang terlalu banyak, dan tentunya akan memengaruhi air susunya menjadi tidak lancar atau lama keluar Berikut ini hasil wawancaranya:

"Tidak terganggu, iya tapi biasa juga cape, cuma itu biasa kalau banyak bekerja, kurang keluar air susu saya." (JR, 33 thn., 03/07/2019).

Berbeda dengan yang dialami informan HB. Apabila saat ibu menyusui bayi dan tiba-tiba ada pembeli, maka ibu terpaksa menghentikan kegiatan menyusui untuk melayani pembeli tersebut. Jika ibu sudah selesai melayani ibu langsung melanjutkan untuk menyusui bayinya, 
namun terkadang si bayi tidak mau lagi untuk menyusui. Berikut ini hasil wawancaranya:

"Biasa terganggu karena, biasa masih mau susu anak saya tapi ada orang yang belanja jadi saya hentikan dulu baru saya lanjut untuk menyusuinya lagi. Tapi, biasa anaknya tidak mau lagi." (HB, 33 thn., 03/07/2019)

\section{Tindakan Ibu Menyusui}

Beberapa tindakan ibu dalam menyusui anaknya/bayinya, mulai bagaimana ibu tersebut mempersiapkan ASI untuk bayinya, mengkonsumsi makanan bergizi agar produksi ASI banyak, berapa lama ibu harus menyusui dan ibu memberikan ASI saja sampai usia enam bulan.

\section{Mempersiapkan Kelahiran Bayi dengan Perawatan Payudara}

Dari hasil wawancara dengan informan di bawah ini tentang bagaimana persiapan kelahiran bayi dengan perawatan payudara, berikut hasil wawancaranya:

"Waktu saya hamil tidak ada begitu karena normal payudara saya, paling dibersihkan saja karena kalo hamil cepat sekali berminyak payudara saya" (HM, 42 thn., 03/07/2019).

Berdasarkan hasil wawancara dengan HM, pada saat hamil ibu tidak melakukan perawatan khusus untuk payudara karena payudaranya normal dan hanya dibersihkan saja karena ibu merasa payudaranya berkeringat. Lain halnya dengan informan JR yang mengatakan bahwa payudara dibersihkan. Hal ini dikarenakan pada saat ibu sedang hamil puting payudara masuk ke dalam, sehingga diperlukan usaha untuk mengeluarkan putingnya agar ketika bayi lahir ibu tidak susah menyusui.

"Mau dirawat bagaimana, paling dibersihkan, biasa memang ada payudaranya $i b u$, masuk kedalam putingnya, memang itu harus di kasi keluar karena susah." (JR, 33 thn., 03/07/2019).
Sedangkan berdasarkan wawancara dari informan $\mathrm{HB}$, mengatakan kalau tidak ada perawatan khusus yang dilakukan terkecuali, dia membersihkan seperti biasa saja. Karena ibu merasa puting susunya bagus dan tidak masuk kedalam. Berikut ini hasil wawancaranya:

"Tidak ada perawatan khusus bu, karena bagus puting susu saya. Paling itu biasa saya bersihkan." (HB, 35 Thn., 03/07/2019).

\section{Ibu Mengonsumsi Makanan untuk Kelancaran ASI}

Dari hasil wawancara dengan informan di bawah ini tentang apakah ibu mengonsumsi makanan bergizi agar ASInya lancar, berikut hasil wawancaranya:

\begin{abstract}
"Waktu saya menyusui pertama-pertama saya disuruh makan kacang goreng supaya banyak ASI saya tapi kalo makan, seperti biasa kalo saya makan hari-harinya ada nasi, sayur dan ikan saja, tidak ada makanan khusus." (HM, 42 thn., 03/07/2019).
\end{abstract}

Berdasarkan kutipan dari informan HM, bahwa ketika awal menyusui, ibu diminta untuk mengonsumsi kacang goreng karena dapat memperbanyak ASI. Ibu mengonsumsinya didukung dengan konsumsi nasi, sayur, dan ikan setiap harinya. Lain halnya dengan informan JR, ibu tidak mengonsumsi makanan khusus untuk memperlancar ASI. Ibu hanya disarankan banyak mengonsumsi sayur supaya air susunya lancar. Tetapi ibu tersebut tidak suka mengonsumsi sayur. Berikut ini hasil wawancaranya:

"Tidak ada yang saya makan, kalo makan seperti biasa makanan hari-hari tapi disuruh memang banyak makan sayur supaya banyak katanya air susuku, tapi biasa saya tidak suka makan sayur.” (JR, 37 thn., 10/07/2019).

Sedangkan berdasarkan kutipan dari informan HB, mengatakan ketika ASInya tidak lancar maka ibu akan mengonsumsi sayuran hijau seperti daun katuk untuk memperlancar ASI, 
karena informan HB juga suka mengkonsumsi sayur. Berikut ini hasil wawancaranya:

"Kalau saya bu, biasa makan daun katuk atau sayur-sayuran yang hijau supaya banyak ASIku, kebetulan saya suka makan sayur, jadi sayur apa saja suka semua." (HB, 35 thn., 10/07/2019).

\section{Lama Menyusui Bayi}

Dari hasil wawancara dengan informan di bawah ini tentang apakah ibu lama menyusui bayi dan berapa lama, berikut hasil wawancaranya:

"Waktu baru melahirkan, lumayan lama biasa sampai 10 menit tapi waktu anakku umur 4 bulan berkurang jadi saya kasih bubur saring" (HM, 42 thn., 10/07/2019)

Berdasarkan kutipan dari informan HM, ASI ibu tidak lancar pada saat bayinya mulai berumur 4 bulan sehingga bayi tidak merasa puas dan diberikan makanan tambahan berupa bubur saring. Lain halnya dengan informan JR yang mengatakan kalau menyusui anak atau bayinya kadang lama kadang tidak. Ibu bayi berasumsi bahwa kalau bayinya sudah kenyang dia akan berhenti sendiri dan ibu biasa menyusui hingga sampai 10 menit.

"Biasa lama, biasa juga cepat tergantung itu anak. Kalo sudah kenyang berhenti sendiri itu, biasanya 10 menit sudah cukup." (JR, 37 thn., 10/07/2019).

Berbeda dengan dua informan sebelumya, HB mengungkapkan kalau menyusui bayinya agak lama atau sampai bayinya sudah kenyang dan berhenti sendiri. Berikut ini hasil wawancaranya:

"Kalo saya lumayan lama bu karena kuat itu anak saya menyusui. Itupun kalau sudah kenyang pasti berhenti." (HB, 35 thn., 03/07/2019).

\section{Ibu Memberikan ASI Saja Sampai Umur Enam Bulan}

Dari hasil wawancara dengan informan di bawah ini tentang apakah ibu memberikan ASI saja sampai umur enam bulan, berikut hasil wawancaranya:

"Eeee...tidak bu karena kurang air susuku, jadi saya bantu bubur waktu umur enam bulan, kurang sekali ASI saya jadi tidak bisa kalo susu saja dibantu sama makanan bu." (HM, 42 thn., 03/07/2019)

Berdasarkan hasil kutipan informan HM, dikarenakan produksi ASI yang kurang, maka anak tidak merasa kenyang. Ibu kemudian memberikan makanan berupa bubur saring agar anak cepat tumbuh. Sedangkan informan JR mengatakan kalau dia mengetahui bahwa sebaiknya bayi hanya konsumsi ASI saja sampai umur 6 bulan, sehingga ketika usia bayi sudah lewat dari enam bulan baru si ibu mulai memberikan makanan pendamping kepada anaknya. Berikut ini hasil wawancaranya:

\section{"Iya bu, saya kasi susu saja sampai umur enam bulan. ASI saja saya kasi tidak ada campurannya, nanti lewat enam bulan baru saya kasi makanan bubur." (JR, 37 thn., 03/07/2019)}

Begitupun dengan informan $\mathrm{HB}$, mengatakan hal yang sama seperti yang diungkapkan oleh informan JR. Kalau ibu juga menyusui anak atau bayinya hingga berusia enam bulan tanpa tambahan makanan lain. Berikut ini hasil wawancaranya:

"Iya bu, saya kasi susu saja sampai umur enam bulan. ASI saja saya kasi tidak ada campurannya, nanti lewat enam bulan baru saya kasi makanan bubur." (HB, 37 thn., 03/07/2019)

\section{Promosi Susu Formula}

Susu formula adalah cairan yang berisi zat yang mati, di dalamnya tidak ada sel hidup seperti sel darah putih, zat pembunuh bakteri, antibodi, enzim, hormon, dan juga tidak mengandung faktor pertumbuhan. ${ }^{14}$ 


\section{Bayi Diberikan Susu Formula}

Dari hasil wawancara dengan informan di bawah ini tentang bagaimana bayi diberikan susu formula, berikut ini hasil wawancaranya:

"Waktu anak saya lahir pas masi tiga minggu saya sudah kasih susu formula, masalahnya anak/bayi saya terlalu menangis dan saya sibuk bekerja." (HM, 25 thn., 10/07/2019).

Berdasarkan kutipan dari informan HM, ibu lebih mementingkan pekerjaan ketimbang mengurus bayinya. Danibu mengungkapkan kalau bayinya sering menangis karena membutuhkan ASI namun karena ASI kurang sehingga bayi diberikan susu formula. Sama halnya dengan informan JR yang mengatakan kalau ASInya tidak lancar saat bayi baru lahir. Jadi, ibu lebih memilih bayinya mengonsumsi susu formula. Berikut ini hasil wawancara:

"Kalau saya, air susuku waktu melahirkan ada keluar sedikit itu pun hanya beberapa menit saja. Jadi saya kasih minum saja susu formula" (JR, 37 thn., 10/07/2019).

\section{Dampak dari Susu Formula}

Dari hasil wawancara dengan informan di bawah ini tentang bagaimana pengetahuan ibu tentang dampak dari susu formula, berikut ini hasil wawancaranya:

"Eee... saya kasih susu formula kepada bayi saya pada saat usia satu bulan dan saya lihat anak saya buang-buang air. Tapi saya tetap kasih minum, mau bagaimana kalau tidak kasih minum anak saya tidak puas dengan ASI saya walaupun ASI saya lancer." (JR, 37 thn., 10/07/2019).

Berdasarkan hasil kutipan dari informan JR, mengatakan kalau ibu sudah mengetahui efek pemberian susu formula, namun ibu tetap memberikannya walaupun bayi sering buangbuang air karena pemberian susu formula. Sedangkan informan WT mengungkapkan bahwa
ASInya lancar tetapi ibu sangat malas menyusui bayinya. Ibu lebih mementingkan kecantikan agar badannya tidak gemuk karena ibu yang menyusui cenderung cepat lapar dan selalu ingin makan. Berikut ini hasil wawancaranya:

"Air susu saya selalu lancar, tapi saya malas untuk menyusui anak/bayi saya. Soalnya jika selalu menyusui bodi badan saya terlalu cepat gemuk akibatnya cepat lapar dan terlalu banyak makan. Jadi, anak saya baru usia 1 bulan 5 hari, saya sudah tidak menyusui lagi dan anak saya kelihatan kurus dan sakit-sakit karena efek dari susu formula walaupun saya sudah tua." (WT, 25 thn. 10/07/2019).

Lain halnya dengan informan RM yang tidak mengetahui dampak susu formula. Bayi diberi susu formula secara berselang dengan ASI, tetapi setelah beberapa waktu bayinya gatal-gatal, dan ternyata itu merupakan efek susu formula sehingga ibu menghentikan selama beberapa waktu. Tetapi karena anak bayi ibu sudah terbiasa dengan susu formula maka ibu tetap memberikan susu formula. Berikut ini hasil wawancaranya:

"Wahh...saya tidak tau efek atau dampak dari susu formula jadi saya kasih minum saja susu formula, walaupun saya kasih susu dengan ASI, tapi kuselang-seling supaya anak tidak menangis. Tapi, anak saya gatalgatal pas saya bawa ke dokter baru saya tau kalau itu efek dari susu formula dan saya sudah menghentikannya selama tiga minggu, tapi anak saya sudah terbiasa dengan susu formula jadi kalau tidak di kasih minum anak/bayi saya menangis. Maka saya kasih minum saja." (RM, 33 thn., 10/07/2019).

\section{Percaya dengan Iklan Susu Formula}

Dari hasil wawancara dengan informan di bawah ini tentang bagaimana pengetahuan ibu tentang iklan susu formula. Berikut ini hasil wawancaranya:

"Wah... saya percaya karena biasa saya nonton TV sering saya melihat ada iklan tentang susu formula. Karena itu, saya 
melihat anak yang ditayangkan di TV jika minum susu anaknya tumbuh lebih cepat dan cepat gemuk jadi saya kasih minum anak/ bayi saya dan anak saya kelihatan gemuk, tapi sering buang-buang air atau mencret." (RM, 33 thn., 10/07/2019).

Berdasarkan kutipan dari informan HM, mengatakan kalau ia mendapatkan informasi melalui iklan susu formula. Ibu melihat anak atau bayi yang ditayangkan di TV, cepat tumbuh besar, meskipun pemberian susu formula membuat bayinya sering mencret. Sedangkan HM mengatakan tidak percaya dengan iklan atau produk-produk tersebut. Ia menganggap karena ibu sibuk dengan pekerjaannya dan anaknya sering rewel, bayinya tidak puas dengan ASI. Jadi walaupun tidak percaya tetap saja ibu memberikan susu formula kepada bayinya. Berikut ini kutipan dari informan HM sebagai berikut:

"Sebenarnya saya tidak percaya dengan iklan yang di tayangkan TV. Tapi, karena saya sibuk bekerja dan anak saya terlalu rewel maka saya kasih minum saja susu formula supaya tidak menangis." (HM, 42 thn., 10/07/2019).

\section{PEMBAHASAN}

\section{Pengetahuan}

\section{Pengetahuan Ibu tentang ASI Eksklusif}

WHO menyatakan bahwa pemberian ASI eksklusif tanpa makanan lain kepada bayi sejak lahir sampai dengan enam bulan kecuali obat dan vitamin. Namun, bukan berarti setelah pemberian ASI eksklusif pemberian ASI dihentikan tetapi tetap diberikan kepada anak atau bayi sampai berusia dua tahun. ${ }^{9}$

Berdasarkan hasil wawancara dengan informan tentang informasi manfaat ASI eksklusif, hasilnya menunjukkan bahwa mereka tidak memahami sepenuhnya tentang ASI esklusif. Tentunya diharapkan adanya dukungan dari lingkungan sosial dari ibu tersebut agar dapat memberikan ASI eksklusif untuk bayinya. Untuk itu, selain petugas kesehatan maka peran dan dukungan di sekitarnya haruslah berjalan seperti dukungan keluarga, orang-orang yang ada di sekitarnya, dan komunitas dari ibu-ibu di dalam kegiatan posyandu yang dapat memberikan informasi tentang manfaat ASI eksklusif tersebut agar si ibu dapat merasa nyaman memberikan ASI dan mengasuh bayinya dengan baik.

Menurut Green dalam Notoatmodjo, ${ }^{15}$ pengetahuan merupakan salah satu faktor predisposisi yang menentukan perilaku kesehatan. Salah satu penyebab adanya masalah kurangnya gizi bayi adalah ketidaktahuan ibu akan manfaat ASI, hal tersebut diakibatkan belum sempurna tingkat pengetahuan dan pendidikan terutama pengetahuan tentang pemberian ASI eksklusif. ${ }^{14}$

\section{Pengetahuan tentang Kolostrum}

Hasil wawancara dengan HM sejalan dengan penelitian yang dilakukan oleh Sukari, dkk ${ }^{16}$ di Puskesmas Bahu Manado yang mengemukakan bahwa pengetahuan ibu postpartum tentang pengertian kolostrum, reflek yang berperan dalam kolostrum, komposisi kolostrum, manfaat kolostrum, faktor-faktor yang menyebabkan seorang ibu tidak memberikan kolostrum, keuntungan dalam memberikan kolostrum di Puskesmas Bahu Manado berada dalam kategori baik.

Hasil penelitian di atas sejalan dengan penelitian dimana terdapat informan yang mengetahui manfaat dari kolostrum dan informan tersebut menerapkannya. Karena kolostrum merupakan bagian dari ASI yang sangat penting untuk diberikan pada kehidupan pertama bayi. Kolostrum mengandung zat immunoglobulin untuk melindungi bayi dari berbagai penyakit infeksi dan zat ini tidak akan ditemukan dalam ASI selanjutnya ataupun dalam susu formula. Selain itu kolostrum juga mengandung protein, vitamin A yang tinggi, dan lemak rendah yang sesuai dengan kebutuhan gizi bayi pada hari pertama kelahiran, oleh karena itu kolostrum harus diberikan kepada bayi. ${ }^{17}$

Sebagian informan mengatakan kalau 
mengetahui tentang kolostrum namun dia tidak mengetahui cairan yang pertama keluar dari ASI, hanya saja informan mengetahui dari warnanya dan melihat pada waktu pertama menyusui, dan tidak memberikan kepada anak bayinya. Dengan adanya kegiatan pelayanan kesehatan dan dukungan dari sekitar ibu bayi, maka dari sinilah diharapkan agar para ibu bayi mendapatkan suatu informasi yang bermanfaat melalui komunikasi antar sesamanya. Sehingga dapat menimbulkan motivasi bagi para ibu dan percaya diri dalam pengasuhan bayi.

Masalah ini sering kita jumpai, dimana kebiasaan salah yang dilakukan ibu di Indonesia dalam menyusui bayinya yaitu tidak memberikan ASI pada saat menyusui pertama. Cairan yang kental berwarna kuning atau kolostrum itu sendiri seharusnya diberikan kepada bayi tapi dibuang karena menganggap bahwa cairan tersebut menyebabkan sakit perut, oleh karena itu sebelum susu matur (ASI) keluar bayi diberi makanan pengganti seperti air gula dan madu, akibat dari kurangnya pemahaman tersebut maka merugikan kesehatan bayi itu sendiri. ${ }^{10}$

\section{Pengetahuan Ibu tentang Manfaat dan Keuntungan ASI}

Ketidaktahuan manfaat ASI eksklusif, menunjukkan bahwa paraibukurangmendapatkan pengetahuan tentang bagaimana mengasuh bayi dengan pemberian ASI eksklusif. Dengan demikian tentunya diharapkan agar petugas kesehatan dapat memberikan informasi yang berkaitan dengan ASI eksklusif baik itu sebelum menikah, pada masa kehamilan, dan setelah memiliki bayi serta tetap diberikan informasi tentang perlunya menjaga kesehatan ibu, mengonsumsi makanan bergizi yang merupakan kebutuhan bagi bayi dalam bentuk ASI. Karena masih didapatkan ibu yang memberikan makan tambahan bagi bayinya sebelum waktu yang dibutuhkan bagi bayinya. Pengetahuan tentang manfaat ASI bukan saja dari petugas kesehatan maupun di lingkungan masyarakat, tetapi dapat diperoleh juga dari pengalaman ibu yang lebih dahulu memiliki bayi. Selain itu juga dapat diperoleh dari media radio/TV dan membaca informasi yang berkaitan ibu dan anak.

\section{Pengetahuan Ibu tentang Akibat jika Bayi tidak Diberikan ASI Eksklusif}

Pemberian ASI eksklusif sangat dianjurkan pada bayi umur 0-6 bulan karena ASI mengandung gizi yang lengkap untuk pertumbuhan dan perkembangan. Tetapi dalam hal ini ibu bayi tidak menerapkan karena mereka lebih terpengaruh akan perkembangan yang dilihat dari anak bayi tetangga, tanpa memperhitungkan akan penyakit di kemudian hari yang dapat timbul kepada bayi mereka. Hal tersebut tidak sesuai dengan apa yang ditargetkan oleh WHO atau pemerintah. Menurut WHO, pemberian ASI eksklusif berlangsung pada bayi berusia 0-4 bulan. Namun belakangan ini, sangat dianjurkan agar ASI eksklusif diberikan sampai anak usia enam bulan. ${ }^{13}$

Pada penelitian ini terlihat setiap informan mempunyai jawaban yang berbeda-beda, hal ini menunjukkan bahwa pengetahuan tentang ASI eksklusif terhadap mereka masih minim. Ada yang mengetahui namun tidak memberikan ASI eksklusif kepada bayinya. Disamping itu hasil dari wawancara diketahu bahwa ibu memiliki pengetahuan mengenai akibat yang bisa timbul jika bayi tidak diberikan ASI eksklusif dimana bayi rentan akan penyakit, namun demikian pada umumnya masyarakat Banemo memberikan makanan pendamping kepada bayinya walaupun belum cukup enam bulan. Informan memiliki anggapan berdasarkan kebiasaan masyarakat Banemo, jika ASI saja yang diberikan maka bayi tersebut akan lambat pertumbuhannya. Selain itu juga dipengaruhi oleh lingkungan sosial mereka yang berasal dari tetangga, yang mengatakan anak atau bayinya cepat loyo atau lemas jika hanya ASI saja yang diberikan. Dari berbagai alasan yang diberikan oleh para ibu sebab pemberian ASI eksklusif kepada bayinya semakin rendah karena pengaruh dari adanya promosi dari susu formula pengganti ASI, selain itu dari lingkungan sosial dari ibu yang saling mempengaruhi dan 
dipengaruhi tingkat pendidikan dan pengetahuan yang rendah.

\section{Pekerjaan Ibu \\ Jenis Pekerjaan dan Lama Bekerja}

Menurut Suhartin $\mathrm{R}$ dalam Salsabila, ${ }^{18}$ pekerjaan adalah kegiatan yang harus dilakukan seseorang terutama untuk menunjang kehidupannya dan kehidupan keluarganya. Masuknya perempuan dalam dunia kerja sedikit banyak mempengaruhi peran ibu dalam pengasuhan anak. Hasil penelitian menunjukkan, bahwa aktivitas yang dilakukan di rumah tidak memengaruhi pemberian ASI kepada bayi karena pekerjaannya tidak berat.

Menurut Yuliandarin dalam Hanulan Septiani, ${ }^{19}$ bahwa ibu yang bekerja berisiko tidak memberikan ASI eksklusif dibandingkan dengan ibu yang tidak bekerja. Ibu yang tidak bekerja lebih berpeluang untuk memberikan ASI eksklusif sebesar 16,4 kali dibandingkan dengan ibu bekerja. Demikian juga menurut Fahrina dalam Kriselly, ${ }^{20}$ ada yang menyebutkan bahwa proporsi pemberian ASI eksklusif pada ibu yang kurang bekerja lebih banyak dibanding dengan ibu yang bekerja berat.

\section{Selama Bekerja Bayi Tetap Diberikan ASI}

Berdasarkan hasil penelitian tentang jenis lama bekerja dan bayi tetap diberi ASI, yaitu ibu yang memiliki aktivitas tetap memberikan ASI dan pengasuhan yang baik bagi bayinya. Ini menunjukkan bahwa pemahaman tentang pemberian ASI cukup baik dan mereka tidak terganggu sama sekali dalam melakukan pekerjaan rumah tangga dengan pemberian ASI kepada bayinya. Pekerjaan rumah tangga dapat dilakukan sebelum atau sesudah waktu menyusui. Demikian juga dengan ibu yang memiliki usaha kecil-kecilan, sama saja perlakuannya dengan ibu rumah tangga lainnya walaupun timbul kelelahan karena pekerjaan yang lebih. Pengetahuan ibu yang baik mengenai ASI dan bekerja, persiapan ibu baik menjelang dan saat bekerja, tentunya akan memberikan dampak yang besar bagi keberhasilan ibu dalam menyusui.

Seiring dengan penelitian yang dilakukan oleh Latifah et $a^{21}$ di Pesurungan Lor Kota Tegal yang menemukan sebagian besar informan memiliki motivasi yang kuat, perasaan senang, dan bangga karena dapat menyusui bayinya sendiri. Dalam hal ini tentunya diharapkan agar petugas kesehatan meningkatkan perannya dalam menyampaikan kegiatan sosial yang dapat meningkatkan dan mendukung upaya-upaya agar ibu mau menyusui bayinya. Pengetahuan tentang menyusui bisa saja diinformasikan oleh petugas berdasarkan pengalaman pribadi atau pengalaman pihak lain yang dapat disampaikan pada kegiatan posyandu ataupun saat melakukan pelayanan kesehatan.

\section{Pekerjaan Memengaruhi Pemberian ASI}

Berdasarkan hasil penelitian, dari masingmasing informan didapatkan bahwa terdapat perbedaan dalam aktivitas pekerjaan rumah maupun pada saat pemberian ASI kepada bayinya. Informan menyampaikan bahwa walaupun rutin menyelesaikan pekerjaan rumah setiap hari, mereka tetap tidak lupa untuk memberikan ASI kepada bayinya ketika bayi lapar dan menyatakan bahwa itu merupakan kewajiban untuk mengurusnya. Selain itu informan lainnya menyatakan bahwa selain pekerjaan rumah yang dilakukan, mereka tetap memberikan ASI kepada bayinya. Hanya saja pada saat si ibu terlalu lelah bekerja terkadang ASI yang dibutuhkan bayi terlambat keluar. Menurut Nuryanto dalam Yuanti, ${ }^{22}$ ibu yang bekerja mempunyai risiko 1,16 kali untuk menghentikan pemberian ASI dibandingkan ibu yang tidak bekerja. Sedangkan Menurut Asngari Nurdiyanah, ${ }^{23}$ persepsi orang dipengaruhi oleh pandangan seseorang pada suatu keadaan, fakta, atau tindakan. Dalam konteks persepsi ibu bekerja, respon terhadap ASI eksklusif dapat berupa memberikan atau tidak memberikan ASI eksklusif kepada bayinya. 


\section{Tindakan Ibu Menyusui}

\section{Mempersiapkan Kelahiran Bayi dengan Perawatan Payudara}

Berdasarkan hasil penelitian ini, didapatkan bahwa setiap informan memiliki informasi tentang perlakuan terhadap payudaranya. Informan mengatakan kalau tidak ada perawatan khusus untuk payudara dan dengan merawat sendiri karena payudara ibu normal sehingga tinggal membersihkan saja. Sedangkan informan lainnya, ada yang mengeluhkan puting susunya masuk ke dalam, sehingga si ibu harus mengeluarkannya karena akan berpengaruh dan mengalami kesulitan ketika bayi akan menyusui. Oleh karena itu, ibu harus rajin membersihkan payudaranya supaya pada saat ibu selesai melahirkan payudara ibu selalu sehat dan saat menyusui bayi merasa nyaman. Untuk itu perlu perawatan payudara karena payudara merupakan organ penting untuk menghasilkan ASI pada bayi, masalah utama, dan prinsip yaitu bahwa ibu-ibu membutuhkan bantuan dan informasi serta dukungan untuk merawat payudaranya. ${ }^{24}$

\section{Ibu Mengonsumsi Makanan untuk Kelancaran ASI}

Berdasarkan hasil penelitian yang dilakukan yaitu setiap informan mempunyai persepsi masing-masing tentang makanan yang harus dikonsumsi untuk kebutuhan ASI. Informan mengatakan bahwa mengonsumsi kacang goreng dapat membantu agar ASI lancar karena ibu berpikir biarpun sudah mengonsumsi nasi, sayur, dan ikan tetapi ASInya tetap tidak lancar. Selain itu informan lainnya mengatakan bahwa setiap hari diminta untuk banyak makan sayur, namun tidak melakukan karena tidak suka dengan sayur. Padahal dengan banyak makan sayur maka ASI dapat lancar dan bayi sehat. Informan selanjutnya, menyatakan sangat menyukai sayur, terutama sayur yang berwarna hijau seperti daun katuk. Sehingga ASI lancar dan ibu puas pada saat menyusui. Ibu yang menyusui harus cermat dalam menyusun pola makan. Selain pola makan yang seimbang, ibu menyusui juga harus cermat dalam memilih bahan makanan yang dapat memperlancar produksi ASI. Ibu menyusui sebaiknya memperbanyak konsumsi sayuran dan

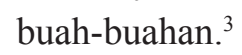

\section{Lama Menyusui Bayi}

Berdasarkan hasil penelitian menunjukkan bahwa informan memberikan jawaban mengenai lama menyusui. Informan mengatakan kalau menyusui bayi bisa sampai 10 menit. Sedangkan informan lainnya mengatakan kalau ibu menyusui bayinya sampai bayi merasa puas baru berhenti menyusui. Penelitian ini sejalan dengan penelitian yang dilakukan oleh Hanson dalam Paramita dan Pramono, ${ }^{25}$ pemberian ASI memiliki peranan penting dalam membentuk sumber daya manusia yang bekualitas dan merupakan upaya kesehatan primer untuk meningkatkan kelangsungan hidup bayi dan anak. Semakin lama seorang ibu menyusui bayinya maka semakin jauh jarak antara kelahiran bagi anak-anaknya, sehingga waktu asuh ibu kepada bayinya lebih optimal dan terbukti memiliki pengaruh positif secara langsung dan tidak langsung terhadap kelangsungan hidup bayi atau anaknya. ${ }^{26}$

\section{Ibu Memberikan ASI Saja Sampai Umur Enam Bulan}

Berdasarkan hasil penelitian ini terlihat bahwa salah satu informan tidak memberian ASI eksklusif sebagaimana yang dianjurkan oleh WHO. Sedangkan dua informan lainnya memiliki persepsi yang sama dengan anjuran WHO dan mereka menerapkan apa yang diharapkan oleh pemerintah tentang pemberian ASI eksklusif yang benar, dimana mereka menyusui anaknya sampai usia enam bulan tanpa makanan tambahan lainnya. Menurut Haniarti dalam Jafar, ${ }^{27}$ manfaat ASI bagi bayi antara lain pemberian ASI memberikan kontrasepsi yang efisien selama enam bulan dan pemberian ASI meningkatkan daya tahan tubuh bayi. 


\section{Promosi Susu Formula}

\section{Bayi Diberikan Susu Formula}

Dari hasil penelitian yang dilakukan, informan lebih memilih produk susu formula dalam mengatasi ketidaklancaran ASI dan tidak berupaya untuk mencari bagaimana cara agar ASI dapat lancar untuk kebutuhan bayinya. Mereka memilih susu formula sebagai alternatif dalam mengatasi ketidaklancaran ASI. Mereka menganggap bahwa memberikan susu formula juga membuat bayi cepat tumbuh besar. Mereka berasumsi bahwa susu formula dapat menjadi pengganti ASI. Padahal fungsi dari susu formula itu diberikan pada saat bayi sudah berusia enam bulan untuk dikonsumsi. Menurut Departemen Kesehatan dalam Yusuf ${ }^{28}$ bahwa susu formula itu tidak terdapat sel darah putih, tidak mengandung enzim, hormone, dan juga tidak mengandung faktor pertumbuhan.

Dalam Peraturan Menteri Kesehatan No. 39 Tahun 2013 tentang Pemberian Susu Formula dan Produk Bayi Lainnya, dijelaskan bahwa pemberian susu formula kepada bayi hanya ditujukan untuk alasan medis. Jadi sebagian informan tidak mengetahui secara baik akan manfaat ASI esklusif bagi bayinya sehingga dengan mudahnya memberikan produk lain seperti susu formula kepada bayinya dalam mengatasi ketidak lancaran ASI mereka. Ini sejalan dengan apa yang disampaikan Novianti dan Rizkianti ${ }^{29}$ bahwa sebagian besar informan gagal memberikan ASI eksklusif dan memberikan asupan prelaktal supaya bayi berhenti menangis karena tangisan bayi diinterprestasikan kelaparan.

\section{Dampak Susu Formula}

Dari hasil penelitian ini didapatkan bahwa informan mengetahui dampak pemberian susu formula sejak bayi, namun ibu tidak melakukan upaya penghentian penggunaan susu formula. Dengan berbagai alasan yang diberikan oleh informan, mereka memberikan susu formula agar bentuk fisik ibu tetap terjaga. Seringnya menyusui anak, maka ibu lebih cepat lapar dan selalu ingin makan, ini dikarenakan bahwa kebutuhan bayi dari ASI tersebut merupakan zat gizi yang berasal dari apa yang dikonsumsi oleh ibunya sehingga tentu saja akan berpengaruh pada kondisi fisik menjadi bertambah gemuk.

Menurut Kepmenkes No. 237/Menkes/SK/ IV/1997 dalam Gunadi, ${ }^{30}$ bahwa susu formula adalah produk makanan yang formulanya dimaksudkan untuk memenuhi kebutuhan gizi bayi dari lahir sampai umur antara 4 dan 6 bulan sesuai dengan karasteristik fisiknya bayi. Sedangkan Menurut Astari dalam Herawati, ${ }^{31}$ penyebab lain terjadinya diare akibat perilaku ibu dalam pemberian susu formula yang tidak benar. Hal ini karena disebabkan karena susu formula merupakan media yang baik bagi pertumbuhan bakteri, sehingga kontaminasi mudah terjadi terutama jika perilaku ibu dalam pemberian susu formula yang tidak benar dan dapat menyebabkan diare pada bayi.

\section{Percaya dengan Iklan Susu Formula}

Berdasarkan hasil penelitian dari kedua informan yang memiliki jawaban hampir sama, yaitu informan mengatakan ia sangat percaya dengan informasi/iklan yang ditayangkan di TV. Sedangkan informan lainnya mengatakan tidak percaya, tetapi ibu beralasan bekerja maka ibu tetap memberikan susu formula kepada bayinya. Hal ini menunjukkan bahwa pemberian susu formula boleh saja namun para informan tidak mengetahui secara benar tentang kapan sebaiknya susu formula diberikan kepada bayinya walaupun kita ketahui bahwa susu formula memiliki banyak kandungan di dalamnya. Tetapi tentunya diharapkan kepada informan maupun lapisan masyarakat yang memiliki bayi untuk dapat memberikan ASI eksklusif tanpa adanya makanan pendamping. Susu formula adalah cairan yang berisi zat yang mati, di dalamnya tidak ada sel hidup seperti sel darah putih, zat pembunuh bakteri, antibodi, enzim, hormon, dan juga tidak mengandung faktor pertumbuhan. ${ }^{14}$

Peraturan yang mengatur peredaran susu formula sangat ringkas dan kurang jelas sehingga masih perlu ditindaklanjuti dengan 
aturan-aturan teknis yang pada kenyataannya tidak terdokumentasi dengan baik. Kegiatan promosi susu formula bayi dan susu formula bayi lanjutan, dilarang menyediakan pelayanan di bidang kesehatan atas biaya yang disediakan oleh badan usaha dengan imbalan promosi susu formula. Selain itu pengetahuan masyarakat di bidang kesehatan bergantung pada aktivitas SDM kesehatan dalam mempromosikan program ASI di wilayah kerjanya, kemampuan mengakses fasilitas kesehatan, serta tersedianya media komunikasi di rumah terutama media elektronik. ${ }^{6}$

\section{KESIMPULAN}

Dari hasil penelitian dapat disimpulkan bahwa kurangnya pengetahuan ibu tentang manfaat pentingnya ASI eksklusif, ibu menyusui yang memiliki kegiatan baik sebagai pekerja maupun sebagai ibu rumah tangga tetap memberikan ASI eksklusif, tidak ada perawatan khusus pada payudara ibu dalam mempersiapkan kelahiran anak, ibu bayi lebih yakin dengan susu formula dengan asumsi bahwa anak bayi lebih cepat tumbuh dan berkembang dengan susu formula berdasarkan informasi yang diperoleh media TV.

\section{SARAN}

Saran dari penelitian ini adalah untuk meningkatkan pengetahuan, sikap, dan perilaku ibu dalam pemberian ASI eksklusif kepada bayi. Pemerintah khususnya bagian program gizi di puskesmas harus mempromosikan tentang ASI eksklusif lebih intensif, dan membuat pesan dan informasi yang sederhana namun mudah dicerna dan dipahami oleh masyarakat, disarankan kepada ibu menyusui agar tidak bekerja lebih berat agar pemberian ASI kepada bayinya lebih maksimal serta melakukan mempersiapkan kelahiran anak dengan melakukan perawatan payudara agar tetap bersih pada saat menyusui. Kementerian Kesehatan dalam hal ini pihak puskesmas harus memonitor fasilitas kesehatan dalam mendukung program ASI eksklusif dan menegakkan disiplin kepada petugas kesehatan yang terlibat mempromosikan susu formula atau makanan padat lainnya dengan sanksi yang tegas. Serta iklan susu formula atau makanan padat di bawah usia enam bulan harus ditegakkan, dan sebaiknya merek susu formula umur di bawah enam bulan tidak boleh sama dengan merek susu formula di atas enam bulan.

\section{UCAPAN TERIMA KASIH}

Terima kasih kami ucapkan kepada semua pihak-pihak yang tidak sempat kami sebutkan satu persatu yang telah membantu dalam pelaksanaan dan kelancaran penelitian ini seperti unsur Puskesmas Banemo Kabupaten Halmahera Tengah, petugas kesehatan dan para informan.

\section{DAFTAR PUSTAKA}

1. Khamzah SN. Segudang Keajaiban ASI Yang Harus Anda Ketahui. Yogyakarta: Flashbooks. 2012.

2. Sugiarti E, Zulaekah S, Puspowati SD. FaktorFaktor yang Berhubungan dengan Pemberian ASI Eksklusif di Kecamatan Karangmalang Kabupaten Sragen. J Kesehat. 2011;4(2):195206.

3. Sutomo B, Anggraini DY. Makanan Sehat Pendamping ASI. DeMedia; 2010.

4. Fikawati S, Syafiq A, Karima K. Gizi ibu dan bayi. Jakarta: Rajawali Pers. 2015. 89-94 p.

5. Kementerian Kesehatan RI. Profil Kesehatan Indonesia 2014. Jakarta: Kementrian Kesehatan RI; 2015.

6. Ogunlesi TA. Maternal Socio-Demographic Factors Influencing the Initiation and Exclusivity of Breastfeeding In A Nigerian Semi-Urban Setting. Matern Child Health J. 2010;14(3):45965.

7. Prasetyono. Buku Pintar ASI Eksklusif (Pengenalan, Praktik, dan KemanfaatanKemanfaatannya). Yogyakarta: Diva Press; 2012.

8. Haryono R, Setianingsih S. Manfaat ASI Eksklusif Untuk Buah Hati Anda. Yogyakarta Gosyen Publ. 2014;1-30. 
9. World Health Organization. Guideline: Protecting, Promoting and Supporting Breastfeeding in Facilities Providing Maternity and Newborn Services. World Health Organization; 2017.

10. Mirani SA, Eni R, Rohmatika D. Tingkat Pengetahuan Ibu Nifas Tentang Colostrum di BPS Harapan Bunda, Ceperan, Sambirejo, Plupuh, Sragen Tahun 2012. Sekolah Tinggi Ilmu Kesehatan Kusuma Husada. 2012.

11. Puskesmas Banemo. Profil Puskesmas Banemo Tahun 2018 [Internet]. blogspot.com. 2019. Available from: http://puskesmasbanemo. blogspot.com/

12. Miles MB, Huberman AM. Analisis Data Kualitatif. Terjemahan Tjetjep Rohendi Rohidi. Jakarta: Penerbit Universitas Indonesia; 1992.

13. Firmansyah N. Pengaruh Karakteristik (Pendidikan, Pekerjaan), Pengetahuan dan Sikap Ibu Menyusui terhadap Pemberian Asi Eksklusif di Kabupaten Tuban. Universitas Airlangga; 2012.

14. Roesli U. Panduan: Inisiasi Menyusu Dini: Plus ASI Eksklusif. Pustaka Bunda; 2012.

15. Notoatmodjo S. Ilmu Perilaku Kesehatan. Vol. 200, Jakarta: Rineka Cipta. 2010. 26-35 p.

16. Sukari NR, Rompas S, Bataha YB. Gambaran Pengetahuan Ibu Postpartum Tentang Kolostrum di Puskesmas Bahu Manado. J Keperawatan. 2014;2(2).

17. Dewi MP, Mahmudah M. Tingkat Pengetahuan Ibu Nifas Tentang Pentingnya Kolostrum Bagi Bayi Baru Lahir di RB Rahayu Tawangmangu Karanganyar. Vol. 4, Maternal. 2011.

18. Habiba S. Faktor-Faktor yang Mempengaruhi Pemberian ASI Eksklusif di Wilayah Kerja Puskesmas Kebakkramat II Kabupaten Karanganyar Tahun 2016. Universitas Negeri Semarang; 2016.

19. Septiani H, Budi A, Karbito. Faktor-Faktor yang Berhubungan dengan Pemberian ASI Eksklusif oleh Ibu Menyusui yang Bekerja Sebagai Tenaga Kesehatan. Aisyah J Ilmu Kesehat. 2017;2(2):159-74.

20. Kriselly Y. Studi Kualitatif Terhadap Rendahnya Cakupan ASI Eksklusif di Wilayah Kerja Puskesmas Kereng Pangi Kecamatan Katingan Hilir Kabupaten Katingan Propinsi Kalimantan Tengah tahun 2012. Skripsi, tidak dipublikasikan, Depok, Universitas Indonesia, Indonesia. 2012.
21. Latifah U, Hidayah SN, Qudriani M. Pengalaman Menyusui Eksklusif Pada Ibu Bekerja Di Pesurungan Lor Kota Tegal. Siklus J Res Midwifery Politek Tegal. 2018;7(1):278-83.

22. Yuanti Y. Perilaku Pemberian ASI Eksklusif dan Faktor-Faktor yang Mempengaruhinya di Puskesmas Kecamatan Cimanggis Depok. J Ilm Kesehat MH Thamrin. 2016;8(1):1-9.

23. Nurdiyanah, Nildawati. Perilaku Pemberian ASI Eksklusif di Puskesmas Bara-Baraya Kota Makassar. Al-sihah Public Heal Sci J. 2015;7(1):76-84.

24. Ronald HS. Pedoman dan Perawatan Kehamilan yang Sehat dan Menyenangkan. Bandung, CV Nuansa Aulia. 2011.

25. Paramita A, Pramono MS. Analisis Pola Dan Faktor Lama Pemberian Air Susu Ibu (ASI) Tahun 2013. Indones J Heal Ecol. 2015;14(2):157-70.

26. Conde-Agudelo A, Rosas-Bermúdez A, KafuryGoeta AC. Effects of Birth Spacing on Maternal Health: A Systematic Review. Am J Obstet Gynecol. 2007;196(4):297-308.

27. Jafar N. Asi Eksklusif. In: Scientific Seminar Studies Program Faculty of Public Health Nutrition Makassar. 2011.

28. Yusuf M. Gambaran Pemberian Susu Formula Pada Bayi Usia 7-11 Bulan di Wilayah Kerja Puskesmas Minasa Upa Makassar Tahun 2011. Fakultas Ilmu Kesehatan Universitas Islam Negeri Alauddin Makassar. Skripsi. 2011.

29. Novianti N, Rizkianti A. Pemberian Asupan Prelakteal Sebagai Salah Satu Faktor Kegagalan Asi Eksklusif Pada Pekerja Buruh Industri Tekstil Di Jakarta. J Kesehat Reproduksi. 2014;5(1):2336.

30. Gunadi SST. Implementasi Peraturan Pemerintah Nomor 33 Tahun 2012 Tentang Pemberian Asi Eksklusif Sebagai Bentuk Perlindungan Hukum Bagi Bayi Terhadap Promosi Susu Formula Bayi di Kota Palembang. Unika Soegijapranata Semarang; 2018.

31. Herawati R, Murni C. Hubungan Pemberian Susu Formula Dengan Kejadian Diare Pada Bayi Usia 0-6 Bulan Di Desa Koto Tinggi Kecamatan Rambah Kabupaten Rokan Hulu. J Martenity Neonatal. 2018;2(5):309. 